\title{
A MINIATURIZATION OF MICROSTRIP ANTENNA USING NEGATIVE PERMITIVITY METAMATERIAL BASED ON CSRR- LOADED GROUNDFOR WLAN APPLICATIONS
}

\author{
Phan Duy Tung, Phan Huu Lam, Nguyen Thi Quynh Hoa* \\ Department of Electronics and Telecommunications, Vinh University \\ 182 Le Duan, Vinh City, Nghe An Province, Vietnam \\ *Email:ntqhoa@vinhuni.edu.vn
}

Received: 3 June 2016; Accepted for publication: 15 August 2016

\begin{abstract}
A microstrip antenna using negative permittivity metamaterial based on complementary split ring resonator (CSRR)-loaded ground has been investigated in order to miniaturize the size and improve the antenna characteristics. The antennas are designed on FR4 material and simulated results are provided by HFSS software. The metamaterial antenna is reduced $77 \%$ the antenna size compared to the normal microstrip antenna. Furthermore, compared with the normal microstrip antenna, the antenna characteristics of the metamaterial antenna are improved significantly. The proposed metamaterial antenna achieves the antenna resonate at $2.45 \mathrm{GHz}$, the gain of higher than $6.5 \mathrm{~dB}$ and the bandwidth of $110 \mathrm{MHz}$ through the whole WLAN band. The obtained results indicate that the proposed antenna is a good candidate for WLAN applications.
\end{abstract}

Keywords: microstrip antenna; metamaterials; split ring resonator (SRR); complementary split ring resonator (CSRR); WLAN.

\section{INTRODUCTION}

Microstrip antennas are of great interest due to their benefit features such as low profile, low cost, planar configuration, and suitable for array with the ease of fabrication and integration with microwave monolithic integrate circuits (MMICs). This promotes them to become the most promising candidates for practical applications such as mobile, radio-frequency identification (RFID), multiple-input multiple-output (MIMO), sensor network, biomedical, wearable systems [1 - 5]. However, this antenna structure is wavelength-related, which makes them difficult to apply in antenna design with compact size.

Various fabrication approaches have been reported to reduce the size of antenna such as the usage of shorting pin, shorting wall and lumped elements [6 - 7]. However, these approaches can make the low bandwidth, efficiency, and gain of antenna [8]. Recently, using metamaterial (MTM) in antenna design has been developed for improving antenna parameters and miniaturizing antenna size [9, 10]. Nevertheless, the approach method is required the sophisticated structures which can be fabricated costly and time consuming. For example, Islam 
et al. reported that a negative index MTM created by combining a modified split-ring resonator (SRR) with a capacitance-loaded strip (CLS) which installed on the radiating patch to obtain the antenna design architecture that simultaneously exhibits both enhanced antenna performance and reduced the antenna size [9]. It was also reported the using of 3D isotropic $\mu$-negative (MNG) MTM loaded on a microstrip circular patch antenna to reduce size and obtain good performance [10].More recently, the use of multi-CSRR resonances etches on ground plane of microstrip antenna for size reduction and gain enhancement [11 - 13]. However, the size reduction is still low (around $10 \%$ [11]) due to the use of multi-CSRR resonances.

In this letter, we report the facial method to miniaturize microstrip antenna based on a single CSRR resonance loaded ground plane. The proposed antenna parameters were simulated and evaluated using HFSS software. Furthermore, the comparative study of microstrip antennas in both with and without CSRR-loaded ground designed at $2.45 \mathrm{GHz}$ were also presented to prove that the size reduction up to $77 \%$ and the enhancement of technical parameters such as gain and bandwidth of microstrip antenna can be realized using a single CSRR resonance.

\section{ANTENNA DESIGN}

Figure 1 shows the geometry of microstrip antennas in both with and without CSRR-loaded ground designed at $2.45 \mathrm{GHz}$. The antennas are designed on FR-4 substrate with dielectric constant of 4.4, loss tangent of 0.02 and height of $0.8 \mathrm{~mm}$. The top and bottom patches are printed on the substrate are the radiating structure and the ground plane.

The dimensions of microstrip antenna without CSRR-loaded ground (referred to as normal antenna) are calculated using the formulas given in [14].Overall and patch dimensions of the normal antenna are $80 \mathrm{~mm} \times 60 \mathrm{~mm}$ and $40 \mathrm{~mm} \times 29 \mathrm{~mm}$, respectively. The antenna is fed by transmission line feeding technique. The size of transmission line was optimized to provide $50 \Omega$ interfaces and achieve the impedance matching at desired frequency as shown in Fig. 1a.

In order to reduce the size of antenna, CSRR unit cell is etched on ground plane [11-13]. The CSRR interacts with the electric field and provides effective negative permittivity its resonance frequency [11]. By etching CSRR on the ground plane, the excitation of these resonators is easily achieved $[11,12]$. The resonance frequency of CSRR depends on the size of the split ring resonator, the gap between the split ring, and the width of the rings. In this design, the size of CSRR unit cell is turned to obtain the desired frequency of $2.4 \mathrm{GHz}$. The optimized dimensions of CSRR unit cell are shown in Fig. 1d. The CSRR unit cell has inner radius is 3.5 $\mathrm{mm}$, outer radius is $6.5 \mathrm{~mm}$, spacing between rings is $1 \mathrm{~mm}$, split gap is $0.5 \mathrm{~mm}$ and width of rings is $1 \mathrm{~mm}$. Then, the CSRR is etched at the center of ground plane of normal antenna and the size of normal antenna is continuously reduced in order to have the design frequency of 2.4 GHz. Dimensions of the microstrip antennas with CSRR-loaded ground (referred to as MTM antenna) is optimized as shown in Fig. 1c. Overall and patch dimensions of the MTM antenna are $39 \mathrm{~mm} \times 28 \mathrm{~mm}\left(0.31 \lambda_{0} \times 0.22 \lambda_{0}\right)$ and $18.6 \mathrm{~mm} \times 14 \mathrm{~mm}\left(0.15 \lambda_{0} \times 0.11 \lambda_{0}\right)$, respectively. It should be noted that both the patch and overall area of the MTM antenna are approximately $77 \%$ smaller than those of normal antenna.

The antennas have been simulated by the commercial HFFS software. 
(a)

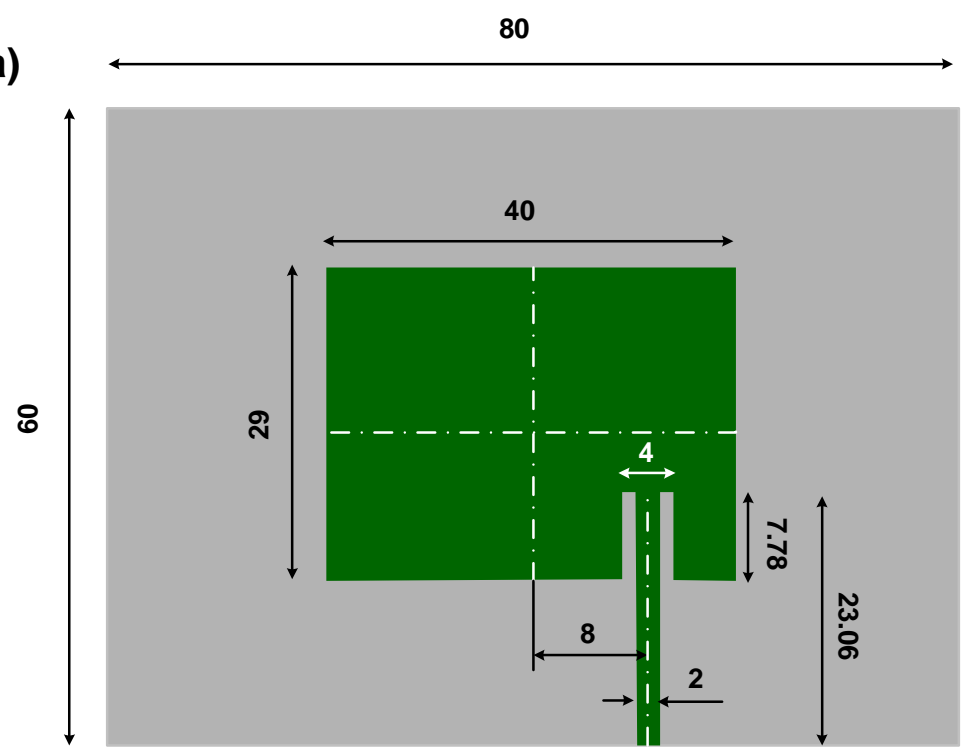

(c)

39

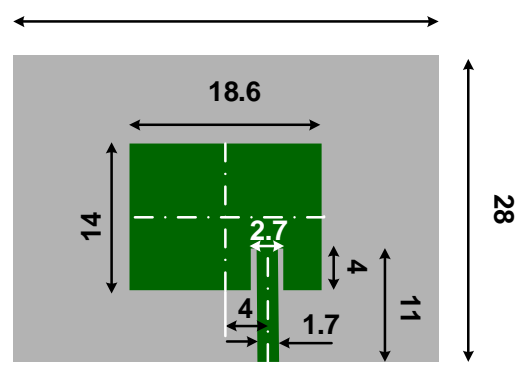

(b)

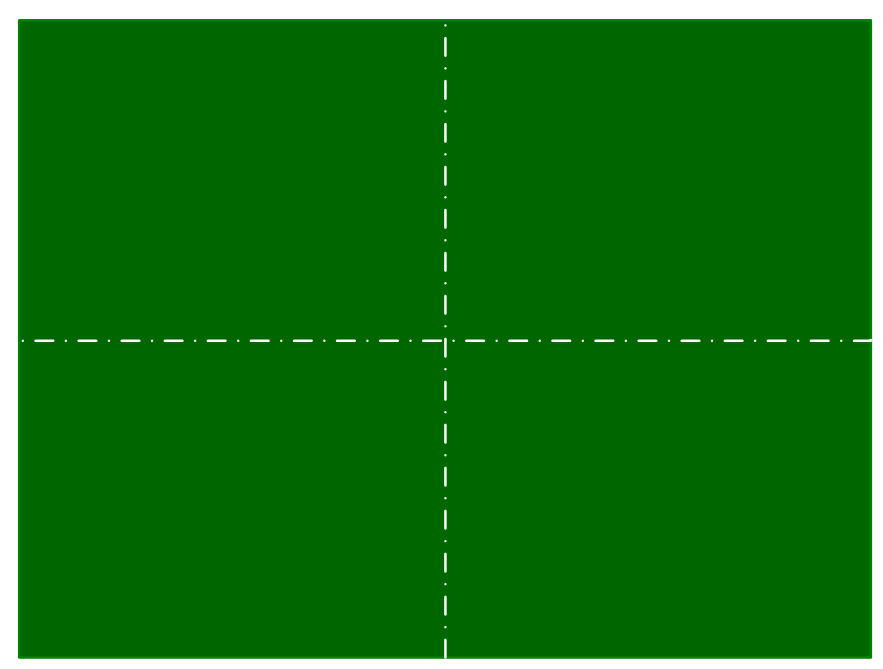

(d)

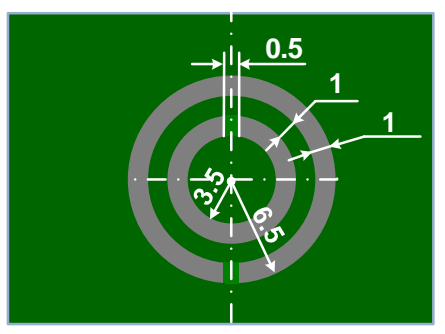

Figure 1. Schematic of antennas: (a) top and (b) bottom view of normal antenna and (c) top and (d) bottom view of MTM antenna (dimensions in $\mathrm{mm}$ ).

\section{SIMULATION RESULTS AND DISCUSSION}

In order to investigate the effect and behavior of the planar MTM structure accurately, the simulation of the SRR unit cell has been performed. The simulation model is shown in Fig. 2a. Two waveguide ports are used at positive and negative locations on the x-axis and excited by an electromagnetic wave in the direction of the x-axis. The perfect electric conductor (PEC) boundary condition is applied to the z-axis, and the y-axis is defined as a perfect magnetic conductor (PMC) boundary. A frequency-domain solver was used for the simulation. The normalized impedance was set to $50 \Omega$. The simulation was performed for the frequency range of $1.0-4.0 \mathrm{GHz}$. 
The S-parameters is extracted and then the permittivity and the permeability are retrieved from S-parameters using Chen's method [15]. The following equations are used to calculate effective permittivity and permeability [15].

$$
\begin{aligned}
& z= \pm \sqrt{\frac{\left(1+S_{11}\right)^{2}-S_{21}^{2}}{\left(1-S_{11}\right)^{2}-S_{21}^{2}}} \\
& n=\frac{1}{k_{0} d}\left\{\left[\operatorname{Im}\left[\ln \left(e^{i n k_{0} d}\right)\right]+2 m \pi\right]-i \operatorname{Re}\left[\ln \left(e^{i n k_{0} d}\right)\right]\right\} \\
& e^{i n k_{0} d}=\frac{S_{21}}{1-S_{21} \frac{z-1}{z+1}} \\
& \mathcal{E}=\frac{n}{z} \\
& \mu=n z
\end{aligned}
$$

where $S_{11}$ and $S_{12}$ are reflection and transmission coefficients, respectively; $k_{0}$ is the wavenumber; $d$ is the maximum length of the unit element; $m$ is the integer related to the branch index of $\mathrm{n} ; \mathrm{n}$ is the refractive index and $\mathrm{z}$ is the wave impedance; $\mu$ is the permeability; and $\varepsilon$ is the permittivity.

From the right hand of equation (2), the imaginary part of $n$ is not affected by the branches of the logarithm function, but the real part is complicated by branches of the logarithm function. In order to verify that the parameters are correct, the plot of parameters versus frequency should be observed which must be continuous. Thus brand index must be selected to satisfy this condition. In this work, we have chosen brand index is zero and obtained the plot of parameters of permittivity and permeability as shown in Fig. 2b,c. Moreover, in order to check more accurate the branch index of n, we used the Kramers-Kronig retrieval method [16]. As shown in Fig. 2b, c, the CSRR unit cell shows negative permittivity band that lies between around 2.4 to 2.5 GHz. It indicates that the CSRR unit cell presents the negative permittivity metamaterial at desired resonance frequency band. The similar results were also observed by other groups [17, 18].

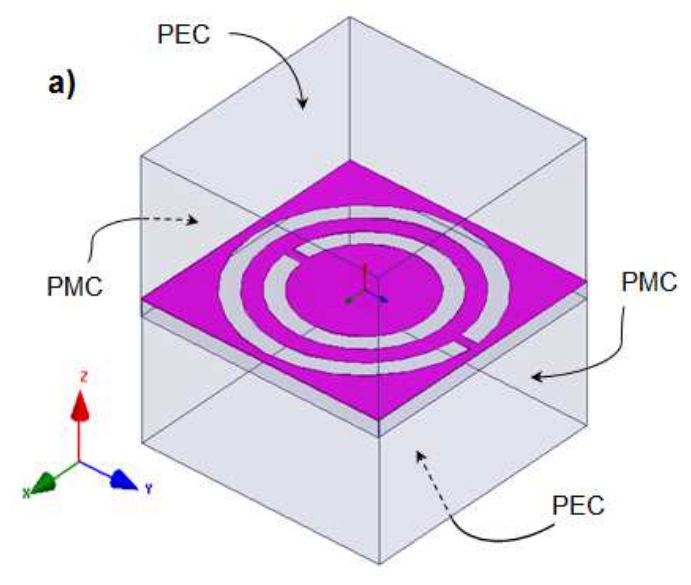

b)

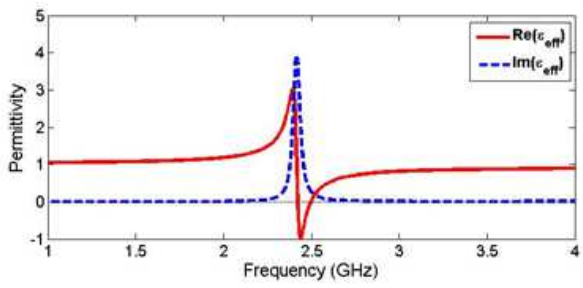

c)

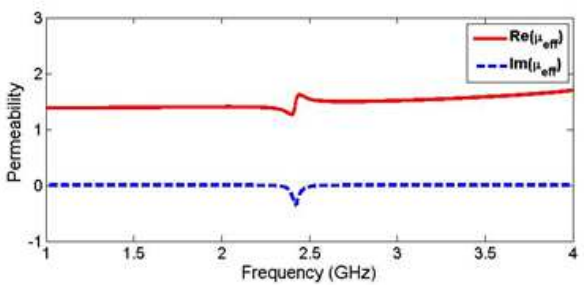

Figure 2. Simulation model (a), retrieved effective permittivity (b) and permeability (c) from S-parameters. 
To evaluate the effect of using CSRR MTM structure on microstrip antenna design, the technical parameters of both normal and MTM antennas were carried out. Fig. 3 shows the reflection coefficient $\left(\mathrm{S}_{11}\right)$ of both normal and MTM antennas. Both antennas work at the same resonance frequency range of $2.4 \mathrm{GHz}$. The MTM antenna exhibits $\mathrm{S}_{11}$ of less than $-10 \square \mathrm{dB}$ in a bandwidth ranging from 2400 to $2510 \mathrm{MHz}$, which entirely covers WLAN frequency band allocated from $2400 \square \mathrm{MHz}$ to $2480 \square \mathrm{MHz}$ [19].Compared to normal antenna, the absolute value of $S_{11}$ of MTM antenna of $35 \mathrm{~dB}$ is enhanced significantly. Moreover, the bandwidth of MTM antenna of $110 \mathrm{MHz}$ is much higher than that of normal antenna of $60 \mathrm{MHz}$. The obtained-10 dB fractional bandwidth of MTM antenna is $4.5 \%$ at center frequency of $2.45 \mathrm{GHz}$.

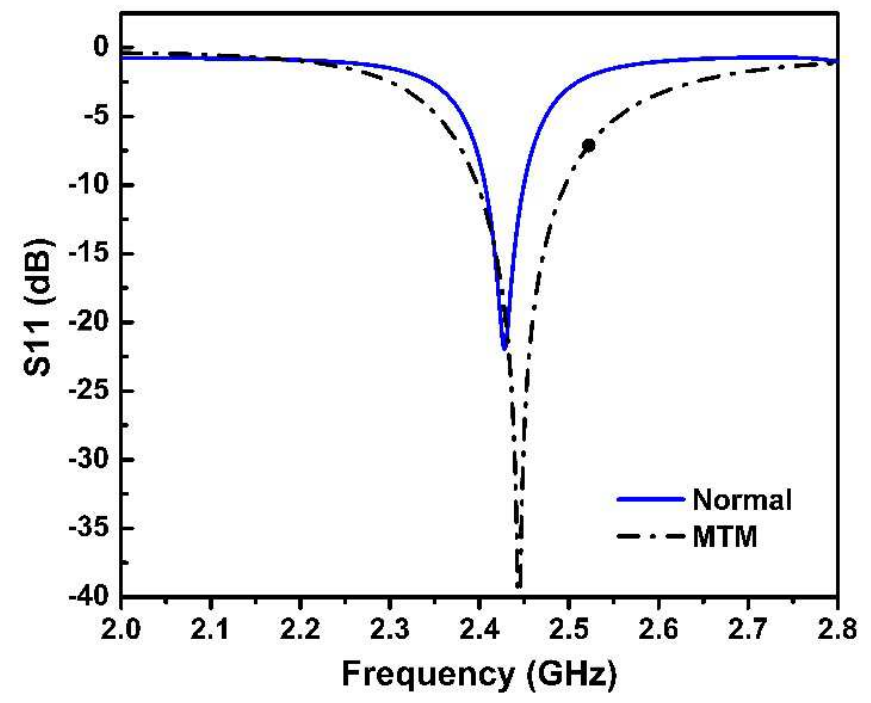

Figure 3. Reflection coefficients of the normal and MTM antennas.

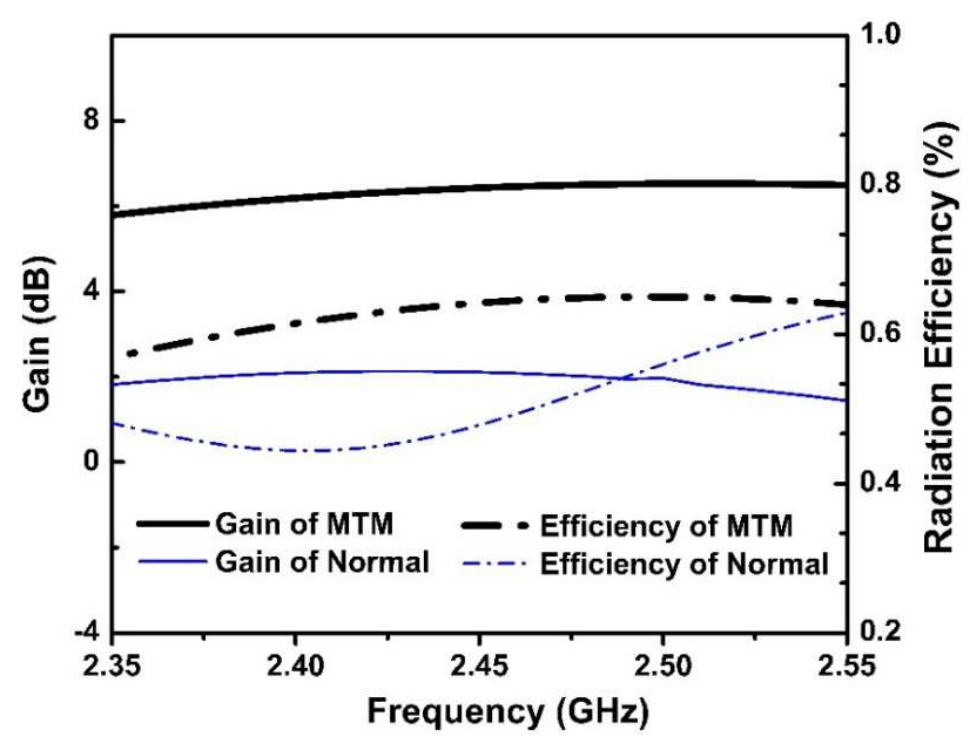

Figure 4. Gain and radiation efficiency of the normal and MTM antenna. 


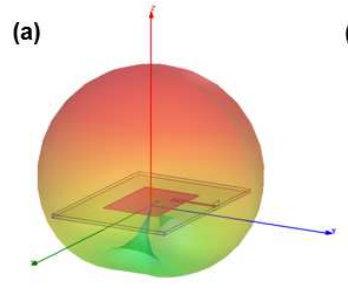

(b)

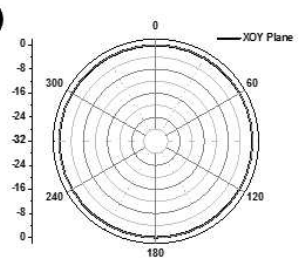

(e)

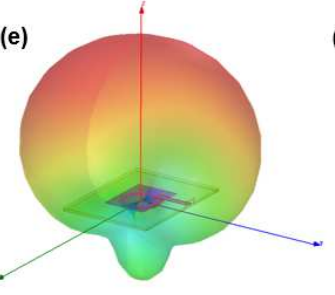

(c)

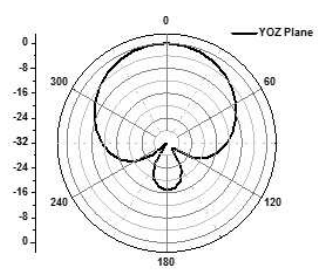

(g)

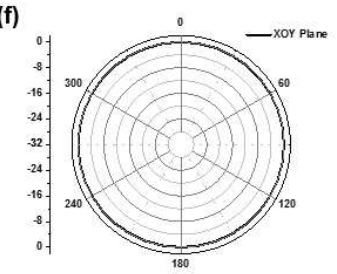

(d)

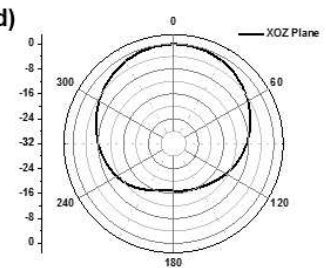

(h)

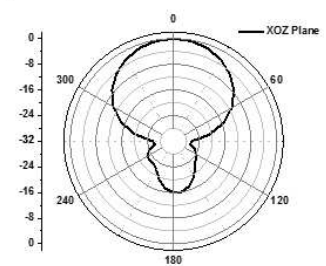

Figure 5. Radiation of the normal and MTM antennas: (a), (e) 3-D radiation pattern; (b), (f) xoy-plane; (c), (g) in yoz-plane; (d), (h) in xoz-plane, respectively.

The gain and radiation efficiency of the normal and MTM antennas in frequency band from $2.35 \mathrm{GHz}-2.55 \mathrm{GHz}$ are investigated. Fig. 4 shows the gain and radiation efficiency of both normal and MTM antennas. As shown in Fig. 4, the peak gain and radiation efficiency of normal antenna are below $2.29 \mathrm{~dB}$ and $53 \% \mathrm{~dB}$ in a bandwidth ranging from 2400 to $2480 \mathrm{MHz}$, respectively. Compared with normal antenna, both peak gain and radiation efficiency of MTM antenna are improved significantly. The gain of MTM antenna is above $6.22 \mathrm{~dB}$, meanwhile, the efficiency remains above $61 \%$ in the working band and the maximum efficiency around $65 \%$ at the resonance frequency.
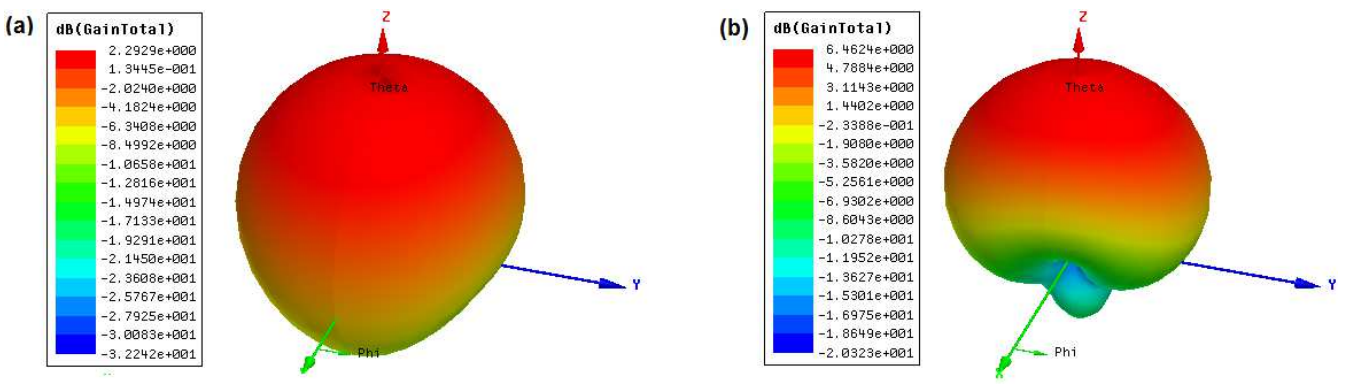

Figure 6. 3D gain pattern of (a) the normal and (b) MTM antennas.

Figure 5 shows the directional radiation patterns of the normal and MTM antennas. Both antennas have quite similar the directional radiation patterns with maximum power along z-axis in yoz-plane and xoz-plane. In xoy-plane, both antennas exhibit an omnidirectional radiation pattern.

The obtained peak gains of normal and MTM antennas are $2.29 \mathrm{~dB}$ and $6.46 \mathrm{~dB}$ at the resonance frequency, respectively were shown in Fig. 6. The 3-D total gains confirm that the maximum power of both antennas could be achieved along z-axis. 
The above results indicate that microstrip antenna with CSRR loaded ground plane achieves size reduction as well as antenna characteristics improvement such as gain and bandwidth. The mechanism of reducing size of microstrip antenna using CSRR can be explained though the resonance of CSRR which have smaller size than operating wavelength $[11,12]$. Therefore, the shift in resonant frequency to a lower value when CSRR is loaded ground plane of antenna is main reason in reducing antenna size. It was reported that the effective permittivity crosses zero at the near resonance frequency. At this frequency, the phase velocity in the substrate tends to be infinite and the resonance frequency of antenna becomes independent with the physic size of antenna [12]. Meanwhile, the bandwidth enhancement can be explained by the reduced Q of the substrate due to the energy leakage through the aperture in the CSRR [12]. Furthermore, the mechanism of improving the characteristics of metamaterial antenna was reported in many literature studies [20,21].

Table 1. Comparison between the proposed antennas and other planar antennas.

\begin{tabular}{|c|c|c|c|c|c|c|}
\hline Ref. & $\begin{array}{c}\text { Frequency } \\
(\mathbf{G H z})\end{array}$ & $\begin{array}{c}\text { Overall } \\
\text { antenna size }\end{array}$ & $\begin{array}{c}-\mathbf{1 0 ~ d B} \\
\text { fractional } \\
\text { bandwidth }(\%)\end{array}$ & $\begin{array}{c}\text { Radiation } \\
\text { Efficiency }\end{array}$ & $\begin{array}{c}\text { Peak } \\
\text { Gain }\end{array}$ & $\begin{array}{c}\text { Pattern } \\
\text { Type }\end{array}$ \\
\hline Normal & 2.43 & $0.64 \lambda_{0} \times 0.48 \lambda_{0}$ & 2.47 & 0.55 & $2.29 \mathrm{~dB}$ & Directional \\
\hline MTM & 2.45 & $0.31 \lambda_{0} \times 0.22 \lambda_{0}$ & 4.5 & 0.65 & $6.46 \mathrm{~dB}$ & Directional \\
\hline$[11]$ & 2.4 & $0.37 \lambda_{0} \times 0.32 \lambda_{0}$ & 4.2 & - & $5.93 \mathrm{dBi}$ & Directional \\
\hline$[12]$ & 2.5 & $0.4 \lambda_{0} \times 0.24 \lambda_{0}$ & 3.2 & - & $-0.23 \mathrm{~dB}$ & Directional \\
\hline$[22]$ & 2.4 & $0.4 \lambda_{0} \times 0.4 \lambda_{0}$ & 2.1 & 0.25 & $-0.8 \mathrm{dBi}$ & Directional \\
\hline$[23]$ & 2.14 & $0.32 \lambda_{0} \times 0.29 \lambda_{0}$ & 5.3 & 0.7 & $2.6 \mathrm{~dB}$ & Directional \\
\hline$[24]$ & 2.66 & $0.35 \lambda_{0} \times 0.35 \lambda_{0}$ & 12.4 & - & $1.6 \mathrm{dBi}$ & Directional \\
\hline$[25]$ & 3.82 & $0.51 \lambda_{0} \times 0.44 \lambda_{0}$ & 6.8 & 0.96 & $3.85 \mathrm{dBi}$ & Directional \\
\hline
\end{tabular}

Table 1 shows a comparison between the proposed MTM antenna and other planar miniaturized antennas in terms of frequency, overall antenna size, $-10 \mathrm{~dB}$ fractional bandwidth, radiation efficiency, peak gain, and pattern type. It can be observed that the proposed antenna is the most compact planar antenna characterized by high gain and moderate $-10 \mathrm{~dB}$ fractional bandwidth.

\section{CONCLUSION}

A microstrip antenna using negative permittivity MTM based on CSRR-loaded ground has been demonstrated in order to miniaturize the antenna size and improve the antenna characteristics. The designed antenna is simulated and evaluated using HFSS software. The obtained results indicate that the CSRR loaded ground plane of microstrip antenna achieves size reduction as well as enhancement of antenna characteristics. The size of MTM antenna is $77 \%$ smaller than that of the normal microstrip antenna due to the resonance of CSRR. The MTM antenna exhibits the antenna resonate at $2.45 \mathrm{GHz}$, the gain of higher than $6.5 \mathrm{~dB}$ and the bandwidth of $110 \mathrm{MHz}$ through the whole WLAN band. Thus, the presented MTM antenna is suitable for WLAN communication systems. 
Acknowledgements. This work is supported by research fund of Vinh University in 2016 under grand number T2016-05.

\section{REFERENCES}

1. Bahl I. J., Bhartia P. - Microstrip antennas, Artech House, Boston, Mass, USA, 1980.

2. James J. R., Hall P. S., Wood C. - Microstrip antenna theory and design, Peter Peregrinus, 1981.

3. Carver K. R., Mink J. W. - Microstrip antenna technology, IEEE Trans. Antennas Propag. 29 (1) (1981) 2-24.

4. Pozar D. M. - Microstrip antennas, Proc. IEEE 80 (1992) 79-91.

5. Garg R., Bhartia I., Bahl I., Ittipiboon A. - Microstrip antenna design handbook, Artech House, Boston, Mass, USA, 2001.

6. Li R. L., Jean G. D., Tentzeris M. M., Laskar J. - Development and analysis of a folded shorted patch antenna with reduced size, IEEE Trans. Antennas Propag. 52 (2) (2004) 555-572.

7. Waterhouse R., Targonski S., Kokotoff D. - Design and performance of small printed antennas, IEEE Trans. Antenna Propag. 46 (11) (1998) 1629-1633.

8. Khan M. U., Sharawi M. S., Mittra R. - Microstrip patch antenna miniaturization techniques: a review, IET Microw. Antennas Propag. 9 (9) (2015) 913-922.

9. Islam Md. M., Islam M. T., Samsuzzaman Md., Faruque M. R. I., MisranN. and Mansor M. F. - A miniaturized antenna with negative index metamaterial based on modified SRR and CLS unit cell for UWB microwave imaging applications, Materials 8 (2015) 392-407.

10. Bilotti F., Alú A., Vegni L. - Design of miniaturized metamaterial patch antennas with mu-negative loading, IEEE Trans. Antennas Propag. 56 (6) (2008) 1640-1647.

11. Pandeeswari R. and Raghavan S. -Microstrip antenna with complementary split ring resonator loaded ground plane for gain enhancement, Microwave Opt. Technol. Lett. 57 (2) (2015) 292-296.

12. Lee Y., Hao Y. - Characterization of microstrip patch antennas on metamaterial substrates loaded with complementary split ring resonators, Microwave Opt. Technol. Lett. 50 (8) (2008) 2131-2135.

13. Hu J. R. and Li J. S. - Compact microstrip antennas using CSRRstructure ground plane, Microwave Opt. Technol. Lett. 56 (1) (2014) 117-120.

14. Constantine A. Balanis - Antenna theory: analysis and design, 3rd Edition, Wiley John and Son publication, 2005.

15. Chen X., Grzegorczyk T. M., Wu B. I., Pacheco Jr J., Kong J. A. - Robust method to retrieve the constitutive effective parameters of metamaterials. Phys. Rev. E 70 (1) (2004) 016608.

16. Szabo Z., ParkG. H., Hedge R., and Li E. -P.- A unique extraction of metamaterial parameters based on Kramers-Kronig relationship, IEEE Trans. Microw. Theory Tech. 58 (10) (2010) 2646-2653.

17. Beruete M., Aznabet M., Navarro-Cía M., El Mrabet O., Falcone F., Aknin N., Essaaidi M., and Sorolla M. - Electroinductive waves role in left-handed stacked complementary split rings resonators, Opt. Express 17 (3) (2009) 1274-1281. 
18. Mitra D., Sarkhel A., Kundu O. and Chaudhuri S. R. B. - Design of compact and high directive slot antennas using grounded metamaterial slab, IEEE Antennas and Wireless Propag. Lett. 14 (2015) 811-814.

19. Afrough M., Fakharian M. M., Tavakol-Hamedani F. - Compact dual-band suspended microstrip slot antenna with an antipodal parasitic element for WLAN applications, Wireless. Pers. Commun. 83 (2015) 571-579.

20. Rani R., Kaur P. and Verma N. - Metamaterials and their applications in patch antenna: areview,International Journal of Hybrid Information Technology 8 (11) (2015) 199-212.

21. Li L. W, Li Y. N, Yeo T. S., Mosig J. R., and Martin O. J. F. - A broadband and high gain metamaterial microstrip antenna, Appl. Phys. Lett. 96 (2010) 164101.

22. Sharawi M. S., Khan M. U., Numan A. B., Aloi D. N. - A CSRR loaded MIMO antenna system for ISM band operation, IEEE Trans. Antennas Propag. 61 (8) (2013) 4265-4274.

23. Gupta A., Sharma S. K., Chaudhary R. K. - A compact dual-mode metamaterial-inspired antenna using rectangular type CSRR, Progress in electromagnetics research C 57 (2015) $35-42$.

24. Majedi M. S., Attari A. R. - A compact and broadband metamaterial inspired antenna, IEEE Trans. Antennas Propag. 5 (12) (2013) 345-348.

25. Ha J., Kwon K., Lee Y., Choi J. - Hybrid mode wideband patch antenna loaded with a planar metamaterial unit cell, IEEE Trans. Antennas Propag. 60 (2) (2012) 1143-1147.

\title{
TÓM TẮT
}

\section{GIẢM NHỎ KÍCH THƯỚC ANTEN VI DẢI SƯ DỤNG SIÊU VẬT LIỆU CÓ ĐỘ TƯ THẨM ÂM BẰNG CÁCH KHẮC CẤU TRÚC CSRR LÊN MẠTT PHẲNG ĐẤT UUNGG DỤNG CHO WLAN}

\author{
Phan Duy Tùng, Phan Hữu Lâm, Nguyễn Thị Quỳnh Hoa* \\ Khoa Điện tử Viễn thông, Đại học Vinh \\ 182 Lê Duẩn, Thành phố Vinh, Tỉnh Nghệ An, Việt Nam \\ "Email:ntqhoa@vinhuni.edu.vn
}

Anten vi dải sử dụng siêu vật liệu có độ từ thẩm âm dựa trên việc khắc cấu trúc CSRR lên mặt phẳng đất đã được khảo sát nhằm mục đích giảm nhỏ kích thước và tăng hiệu năng của anten. Anten được thiết kế trên nền vật liệu FR4 và các kết quả mô phỏng thu được dựa trên phần mềm mô phỏng HFSS. So với anten vi dải thông thường, anten siêu vật liệu có kích thước giảm nhỏ tới $77 \%$. Bên cạnh đó, các tham số kĩ thuật của anten siêu vật liệu cũng được cải thiện đáng kể. Anten siêu vật liệu đề xuất đạt được tần số cộng hưởng ở $2,45 \mathrm{GHz}$, độ lợi lớn hơn 6,5 $\mathrm{dB}$ và băng thông là $110 \mathrm{MHz}$ trong toàn bộ dải tần WLAN. Các kết quả đạt được cho thấy anten siêu vật liệu đề xuất là phù hợp cho các ứng dụng ở dải tần dành cho WLAN.

Tư khóa: anten vi dải, siêu vật liệu, cộng hưởng vòng hở (SRR), cộng hưởng vòng hở bù (CSRR), WLAN. 